\title{
Sediment composition mediates the invasibility of aquatic ecosystems by a non-native Poaceae species
}

\author{
Composição do sedimento medeia a invasibilidade de ecossistemas aquáticos por uma \\ espécie de Poaceae não nativa
}

José Vitor Botter Fasoli ${ }^{1}$, Thaisa Sala Michelan ${ }^{1}$ and Sidinei Magela Thomaz

${ }^{1}$ Programa de Pós-Graduação em Ecologia de Ambientes Aquáticos Continentais,

Departamento de Biologia, Universidade Estadual de Maringá - UEM, Nupelia,

Av. Colombo 5790, Bloco H-90, CEP 87020-900, Maringá, PR, Brazil

e-mail: jvbfasoli@gmail.com; thaisamichelan@gmail.com; smthomaz@nupelia.uem.br

\begin{abstract}
Aim: To test the invasibility of aquatic ecosystems by an exotic species, we used the invasive macrophyte Urochloa arrecta, which has invaded many Neotropical waterbodies and has reduced biodiversity in these habitats. The extensive growth of this macrophyte can be related to its affinity for mud-rich sediments, which occur primarily in secondary river channels and lentic habitats. Methods: To test this hypothesis, we cultivated $U$. arrecta in trays with different percentages of mud and we measured the sprout length and biomass of the plants after 75 days. Results: Our results showed a positive and significant relationship between sediment mud percentage and nitrogen, phosphorus and organic matter. Both plant length and biomass increased significantly and continuously with increasing mud content, indicating that the growth of this species is not limited even at the highest levels of mud, which is shown to be toxic for other species of macrophytes. Thus, it is probable that sand-rich sites, such as river shores, are less vulnerable to invasion by this species than relatively mud-rich sites, such as lakes. Conclusions: This finding indicates that relatively mud-rich ecosystems should be prioritised in monitoring programs to prevent invasion by this species. In addition, the slow development of this species in sandy sediments opens a potential window for its management, at least on small spatial scales. However, despite the reduced growth of $U$. arrecta in sand-rich sediments, this grass is able to grow in several types of sediments, which explains its spread in a variety of habitats in Neotropical freshwater ecosystems.
\end{abstract}

Keywords: exotic species; aquatic macrophytes; biological invasion.

Resumo: Objetivo: Para testar suscetibilidade de invasão dos ecossistemas aquáticos por uma espécie exótica, nós utilizamos a macrófita invasora Urochloa arrecta, que tem invadido muitos corpos aquáticos neotropicais e reduzido a biodiversidade desses hábitats. O vasto crescimento dessa macrófita pode ser relacionado com sua afinidade por sedimentos ricos em lama, que ocorrem primariamente em canais secundários de rios e hábitats lênticos. Métodos: Para testar essa hipótese, nós cultivamos $U$. arrecta em bandejas com diferentes porcentagens de lama e mensuramos o comprimento e a biomassa das plantas após 75 dias. Resultados: Nossos resultados mostraram uma relação positiva e significante entre a porcentagem de lama no sedimento e nitrogênio, fósforo e matéria orgânica. O comprimento e biomassa das plantas aumentaram significativamente e continuamente com o aumento da porcentagem de lama, indicando que o crescimento dessa espécie não é limitado mesmo nos níveis mais altos de lama, que são mostrados como potencialmente tóxicos para outras espécies de macrófitas. Assim, é provável que sítios ricos em areia, como canais de rios, são menos vulneráveis a invasão por essa espécie do que sítios relativamente ricos em lama, como lagos. Conclusóes: Esses resultados indicam que ecossistemas relativamente ricos em lama deveriam ser priorizados em programas de monitoramento para prevenir a invasão por essa espécie. Além disso, o lento desenvolvimento dessa espécie em sedimentos arenosos abre uma janela potencial para o seu manejo, pelo menos em escalas espaciais menores. Entretanto, apesar do crescimento reduzido de $U$. arrecta em sedimentos arenosos, essa gramínea é capaz de crescer em diversos tipos de sedimentos, o que explica sua dispersão em uma variedade de hábitats em ecossistemas de água doce neotropicais.

Palavras-chave: espécies exóticas; macrófitas aquáticas; invasōes biológicas. 


\section{Introduction}

The susceptibility of an ecosystem to biotic invasion, known as invasibility, is determined by several abiotic and biotic factors, such as resource availability, degree of competition, facilitation, herbivory and pathogens (Tilman, 1999; Davis \& Pelsor, 2001; Thiébaut \& Martinez, 2014). Invasibility is not a static condition and is influenced by the environment's biotic and abiotic events and processes (Davis, 2009). Humans alter ecosystem invasibility by changing the abiotic and biotic filters affecting the system. Eutrophication is an example of human alteration. This process causes enrichment of aquatic habitats in terms of nutrients and organic matter and the probability of invasion by plants increases (Engelhardt, 2011).

Most aquatic macrophytes disperse easily and have rapid growth rates (Santamaria, 2002). Thus, certain species can become invasive given suitable water and sediment conditions. Sediment composition, for example, may determine the success of a macrophyte and influence the structure of macrophyte assemblages (Bornette \& Puijalon, 2011). Sediments have higher concentrations of nutrients than the water column (Esteves, 2011), and they are generally the principal source of nutrients for rooted macrophytes (Carignan \& Kalff, 1980; Esteves \& Camargo, 1986; Bornette $\&$ Puijalon, 2011). Thus, a combination of physical structure (e.g. granulometry), organic matter (OM) and nutrients may be an important determinant of the success of rooted macrophytes.

Certain species of macrophytes grow preferentially in coarse, less organic sediments, which are rich in sand and typical of river channels, whereas others prefer more organic and clay-rich substrates, typical of lakes (Boeger, 1992; Sousa, 2011). If the sediment is rich in OM, the nitrogen $(\mathrm{N})$ and phosphorus $(\mathrm{P})$ concentrations are generally higher (Esteves, 2011). However, independently of the nutrient content, sediment $\mathrm{OM}$ is also an important determinant of macrophyte success and may play a double role, stimulating the development of certain species and hampering others, that grow poorly in highly organic sediments (Barko, 1983; Wu et al., 2009; Sousa, 2011). Thus, the continuous increases in macrophyte development with increasing sediment OM (owing to nutrient enhancement) may not always occur. Furthermore, a threshold of growth beyond which declines occur in sediments that are richer in mud may be found for certain species.
Due to the importance of sediment for macrophyte establishment and growth, the physical and chemical features of this compartment may mediate invasions by non-native macrophytes (e.g., Dukes \& Mooney, 1999; Dethier \& Hacker, 2005; Sousa, 2011). Thus, variability of sediment composition among lakes, ponds, reservoirs and rivers may change the potential for propagation and invasion by non-native species, and analyses of sediment features may help to predict the potential invasibility of these ecosystems.

One of the most invasive and troublesome macrophytes in the Neotropical region is the African Poaceae species Urochloa arrecta (Hack. Ex T. Durand \& Schinz) Morrone \& Zuloaga, described in early studies as Urochloa subquadripara (Thomaz et al., 2009; Michelan et al., 2010a, b). This plant is recorded at high frequencies in lakes, rivers and reservoirs in Brazil (Pott et al., 2011; Thomaz et al., 2009). Its extreme invasiveness is associated with a high regeneration ability via fragments (Michelan et al., 2010a), rapid growth and efficient regeneration after disturbances (Thomaz et al., 2009; Michelan et al., 2010a). Due to these characteristics, the spread of $U$. arrecta (which forms almost homogeneous stands) is of concern because it reduces the diversity of native macrophytes (Pott et al., 2011; Michelan et al., 2010b). U. arrecta is supposed to spread massively and colonise newly available habitats. Surprisingly, however, it does not always increase explosively to the status of an aggressive weed, and it even grows poorly in certain sites (Michelan et al., 2010b). Sediment composition may be a potential factor influencing the success of $U$. arrecta, but information about the causes of the success of this species is still lacking.

In this study, we experimentally investigated the effect of sediment composition on the early stages of development and growth of $U$. arrecta. We hypothesise that invasibility is higher in mud-richer sediments (typical of lentic aquatic ecosystems) than in sand-richer sediments (typical of river shores). Assessing the role of the sediment in the early development and growth of $U$. arrecta would help to predict which habitats are more prone to invasion by this and, most likely, other species of Poaceae.

\section{Material and Methods}

Our experiment was conducted in a greenhouse from January to March 2011. We collected fragments of $U$. arrecta and sediment from the Upper Paraná River floodplain. We 
characterised mud as a mixture of silt and clay (particles $<0.062 \mathrm{~mm}$ ), typical of lentic habitats (Higuti, 2004). The mud-rich sediment was gathered in a floodplain lake. This sediment was composed of $69 \%$ mud and $31 \%$ fine and coarse sand (G. D. Pinha, unpublished data). Sandy sediment was obtained from recently formed islands in the main channel of the Paraná River. This type of sediment contains an undetectable quantity of mud (G. D. Pinha, unpublished data). Sediment was added to plastic trays $(0.33 \times 0.22 \times 0.10 \mathrm{~m})$ to establish five treatments according to the lake:river (expressed as mud sediment:sand sediment) sediment ratios: 0:1 (0\% mud), 1:3 (17.25\% mud), 1:1 (34.5\% mud), $3: 1(51.75 \%$ mud) and 1:0 (69\% of mud). Each treatment was five times replicated. We added three apical fragments of $U$. arrecta to each tray and distributed the trays randomly within the greenhouse. The initial fragment length was $10-12 \mathrm{~cm}$, and the initial mean weight was $5.4 \mathrm{~g}$ (1.8 SD) .

The water level in the trays $(\mathrm{ca} .3 \mathrm{~cm}$ ) was maintained at a constant level by daily additions of tap water. After 75 days, most fragments had developed both above and below-ground structures and were removed and washed. Their length and total biomass (dry weight - DW; obtained after drying at $80^{\circ} \mathrm{C}$ in an oven to constant weight) were then measured. Certain fragments decomposed, indicating that they were not viable. For this reason, we used the mean values of the attributes (plant length and biomass) of the remaining sprouts per tray as response variables.

Sediment samples were collected at the beginning of the experiment in each tray for $\mathrm{N}$, $\mathrm{P}$ and $\mathrm{OM}$ quantification. We determined these nutrients for each sample because they change along the mud:sand gradient and are the most likely determinants of plant growth.

The sediment samples were dried at $60{ }^{\circ} \mathrm{C}$ to constant weight. Total $\mathrm{N}$ and $\mathrm{P}$ were measured in a spectrophotometer after acid digestion, following Zagatto et al. (1981) and Golterman et al. (1978), respectively. Organic matter was determined after calcination in a muffle furnace at $560{ }^{\circ} \mathrm{C}$ for four hours.

\subsection{Statistical analyses}

We first applied a Pearson correlation analysis to the sediment variables ( $\mathrm{N}, \mathrm{P}, \mathrm{OM}$ and mud) to determine how these variables were related. Mud-rich sediments typical of lentic habitats were expected to be richer in nutrients and OM than sand-rich sediments typical of lotic habitats. We synthesised these variables by applying a principal component analysis (PCA). Then, to test the effects of the sediment composition on our response variables, we regressed the scores of the principal component axis 1 (a surrogate for the sediment features) on sprout length and total biomass.

\section{Results}

The individual plant biomass (DW) accumulated after 75 days oscillated from $0.29 \mathrm{~g}(0.15 \mathrm{SD})$ in the treatment $0: 1(0 \% \mathrm{mud})$, to $6.76 \mathrm{~g}(0.9 \mathrm{SD})$ in the treatment 1:0 (69\% of mud). Plant length values fluctuated from $13.62 \mathrm{~cm}(5.44 \mathrm{SD})$ in the treatment $0: 1$ ( $0 \% \mathrm{mud})$, to $101.17 \mathrm{~cm}(12.29 \mathrm{SD})$ in the treatment 1:0 (69\% of mud).

We found high and significant Pearson correlations $(0.90 \leq \mathrm{r} \leq 0.97$; $\mathrm{p}<0.05)$ between the abiotic variables ( $\mathrm{N}, \mathrm{P}, \mathrm{OM}$ and mud). Indeed, $\mathrm{N}$, $\mathrm{P}$ and $\mathrm{OM}$ concentrations increased continuously along a gradient of mud concentrations (Figure 1).

PCA axis 1 summarised $94.9 \%$ of the variation in N, P, OM and mud (the loadings of the variables on axis 1 varied from -0.95 to -0.98 ). Thus, axis 1 furnished a good summary of the four abiotic features of sediment, and the axis 1 scores were used as a new predictive variable. The values of all four variables increased with decreasing axis 1 scores.

The axis 1 scores significantly explained sprout length $\left(\mathrm{R}_{\text {Adj. }}^{2}=0.79 ; \mathrm{p}<0.001\right.$; Figure $\left.2 \mathrm{~A}\right)$ and total plant biomass $\left(\mathrm{R}_{\text {Adj. }}^{2}=0.86 ; \mathrm{p}<0.001\right.$; Figure $\left.2 \mathrm{~B}\right)$. Thus, $U$. arrecta grew poorly in sandy sediments, whereas its growth was much more rapid in muddy sediments, i.e., with higher concentrations of nutrients and OM.

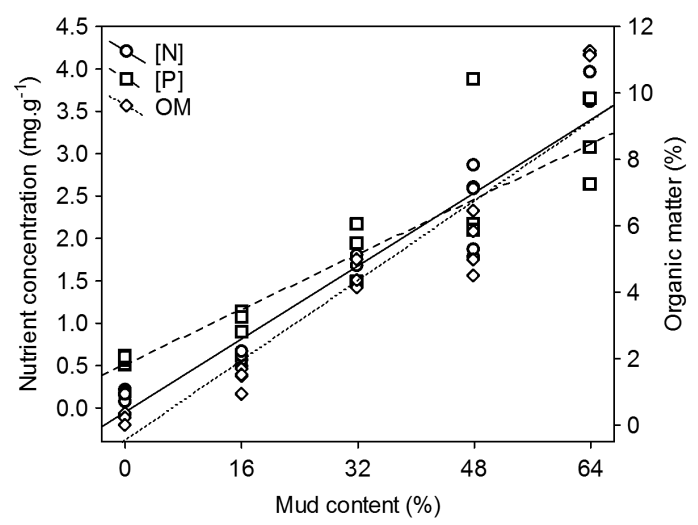

Figure 1. Relationships between mud concentrations and N, P and organic matter (OM) in sediment used in the experiments. 

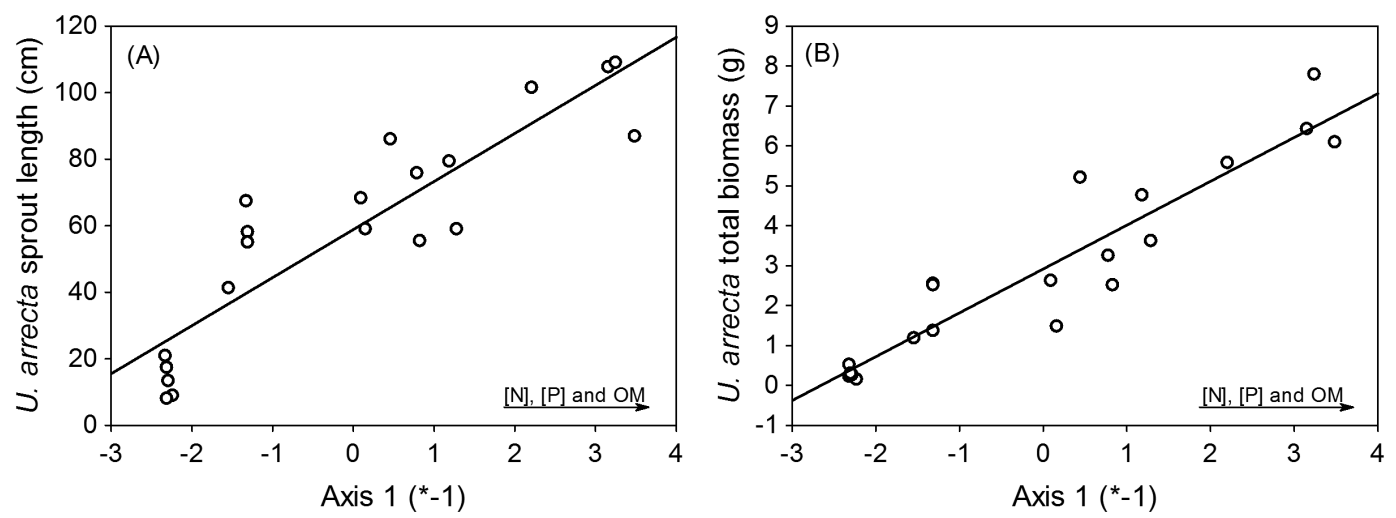

Figure 2. Relationship between $U$. arrecta's sprout length (A) and biomass (B; DW) with the principal component analysis Axis 1 (representing $\mathrm{N}, \mathrm{P}$ and organic matter in the sediment).

\section{Discussion}

The results corroborated our hypothesis by showing that: the development of $U$. arrecta is more rapid in sediments with greater mud content; and the growth of this species is markedly reduced in sand-rich sediments.In fact, according to our experiment, plants grown in sand-rich sediments were approximately ten times shorter and developed approximately seven times less biomass than plants grown in mud. Our results also supported the conclusion that the effects of sediment composition, in terms of the percentage of mud, are most likely mediated by the OM, N and P concentrations because these variables are highly correlated with the sediment mud content. This result was also found in other macrophytes studies (e.g., Boeger, 1992; Katagiri et al., 2011). We highlight that our data was obtained under controlled experimental conditions and thus, direct extrapolation to nature conditions should be carefully taken.

Sediment OM has been shown to play a double role in macrophyte growth because it usually stimulates plant development at low concentrations but reduces plant development at high concentrations, where toxic substances may be released (Wu et al., 2009; Sousa, 2011). However, it appears that even our highest OM content (c. 11\%), typical of floodplain lakes (Sousa, 2011), was not enough to reduce the early development of $U$. arrecta, suggesting that this species has a high potential to invade even sites with sediments rich in OM. Interestingly, this finding contrasts with the characteristics of another invasive macrophyte, Hydrilla verticillata, which recently invaded the Upper Paraná River floodplain, because hydrilla does not develop in the lakes of the Paraná River floodplain, where the sediments are rich in mud and light is limiting (Sousa, 2011). Thus, the contrasting occurrences of these two non-native species in the Paraná floodplain could be partially explained by their different tolerances for sediment composition in terms of OM concentrations.

Together with OM, the nitrogen and phosphorus contents of the sediment have been viewed as important determinants of macrophyte success in freshwater ecosystems (Esteves \& Camargo, 1986; Newbolt et al., 2008). Sediment characteristics are even more important for emergent macrophytes, such as $U$. arrecta, than for submersed ones because the former rely solely on sediment as their source of nutrients, whereas the latter use both water and sediment as nutrient sources (Esteves \& Camargo, 1986; Boeger, 1992).

Based on the results of our experiment, we can also infer that the invasibility by $U$. arrecta of aquatic ecosystems and of sites richer in mud is greater than the invasibility of those ecosystems or sites with sediment poor in mud. Lentic habitats such as floodplain lakes usually have greater mud content in relation to the main river channel (Higuti, 2004; Takeda et al., 2004). Thus, it is probable that these lentic habitats are more easily invaded by this species than are the mud-poor habitats. Lower water velocity also increases the nutrient and OM content of the sediment (Newbolt et al., 2008), what also probably makes backwaters and river secondary channels more vulnerable to invasion than lotic habitats. In the Upper Paraná River floodplain, for example, $U$. arrecta has been recorded only in lakes and lateral channels but never on the shore of the main river channel (TS Michelan, personal observation). We also infer that sand bars and recently formed islands, typical of large rivers such as the Paraná (Agostinho et al., 2004), are less vulnerable to 
invasion by this species. The low invasibility of these islands may be partially determined by the low water content of their sandy soils. However, our results show that physical and chemical features of sandy sediments other than water content also decrease invasibility because all treatments (including the $100 \%$ sand treatment, where $U$. arrecta developed poorly) constantly remained wet. In addition, because macrophytes increase sediment accretion through OM deposition, we expect that $U$. arrecta will facilitate its establishment once it invades a site. Accretion may be a possible explanation for the success of this species in certain streams and rivers (Fernandes et al., 2013).

In sites with sediments richer in OM and nutrients, as simulated in our treatments with higher mud content, it is expected that macrophyte assemblages will move towards competitively dominant and, usually, more rapidly growing species (Jones et al., 2011). U. arrecta is a highly invasive species, and our results show that it grows more rapidly in mud-rich sediments, in agreement with our expectation. As a result, the spread of $U$. arrecta is of concern for the conservation of native macrophytes, especially in more eutrophic ecosystems and in sites with a predominance of muddy sediments, where it is most likely to show a greater potential to grow and to consequently extinct native flora, as shown by the results of a previous investigation (Michelan et al., 2010b).

Finally, we suggest four applications derived directly from our conclusions and inferences. First, our data helps to predict that sand bars and sites that are richer in sand, typically found in several rivers, have a lower probability of invasion by $U$. arrecta than secondary river channels or lentic habitats, whose sediments are richer in mud. Second, as a corollary of this first suggestion, we consider that any monitoring program seeking to assess and prevent invasion by $U$. arrecta should prioritise sites with mud-rich sediments, such as lakes and river lateral channels. Third, the slow development of this species in sand-rich sediments opens a potential window for managing this species. For example, the addition of sand layers should reduce its growth in the long term, and this measure could be effective, at least in small areas. Fourth, because the accretion produced by this species may increase its own invasibility via $\mathrm{OM}$ accumulation, the probability of invasion will be lower if patches of this plant are controlled at an earlier time. Finally, we stress that even though this plant grows poorly in sandy ( $0 \%$ of mud) sediment, our results show that it can grow under a variety of conditions. This characteristic of the plant may explain its spread in Neotropical ecosystems.

\section{Acknowledgements}

We thank Helen C. L. S. Rocha for support during the experimental period. T. S. Michelan acknowledges the Brazilian Council of Research (CNPq) for providing a scholarship, and S. M. Thomaz is especially thankful to the CNPq for continuous funding through a Research Productivity Grant. The present investigation was conducted with the support of CAPES, a Brazilian organisation focused on the formation of human resources.

\section{References}

AGOSTINHO, A.A., BINI, L.M., GOMES, L.C., JÚLIO JUNIOR, H.F., PAVANELLI, C.S. and AGOSTINHO, CS. Fish Assemblages. In S.M. THOMAZ, A.A. AGOSTINHO and N.S. HAHN, orgs. The Upper Paraná River and its floodplain: physical aspects, ecology and conservation. Leiden: Backhuys Publishers, 2004, pp. 223-246.

BARKO, J.W. The growth of Myriophyllum spicatum $\mathrm{L}$. in relation to selected characteristics of sediment and solution. Aquatic Botany, 1983, 15(1), 91-103. http://dx.doi.org/10.1016/0304-3770(83)90102-X.

BOEGER, R.T. The influence of substratum and water velocity on growth of Ranunculus aquatilis L. (Ranunculaceae). Aquatic Botany, 1992, 42(4), 351-359. http://dx.doi.org/10.1016/03043770(92)90054-M.

BORNETTE, G. and PUIJALON, S. Response of aquatic plants to abiotic factors: a review. Aquatic Sciences, 2011, 73(1), 1-14. http://dx.doi. org/10.1007/s00027-010-0162-7.

CARIGNAN, R. and KALFF, J. Phosphorus sources for aquatic weeds: water or sediments? Science, 1980, 207(4434), 987-989. http://dx.doi.org/10.1126/ science.207.4434.987. PMid:17830461

DAVIS, M.A. Invasion biology. New York: Oxford University Press, 2009, 244 p.

DAVIS, M.A. and PELSOR, M. Experimental support for a resource-based mechanistic model of invisibility. Ecology Letters, 2001, 4(5), 421-428. http://dx.doi. org/10.1046/j.1461-0248.2001.00246.x.

DETHIER, M.N. and HACKER, S.D. Physical factors vs. biotic resistance in controlling the invasion of an estuarine marsh grass. Ecological Applications, 2005, 15(4), 1273-1283. http://dx.doi.org/10.1890/040505 .

DUKES, J.S. and MOONEY, H.A. Does global change increase the success of biological invaders? Trends in Ecology \& Evolution, 1999, 14(4), 135-139. http:// 
dx.doi.org/10.1016/S0169-5347(98)01554-7. PMid: 10322518

ENGELHARDT, K.A.M. Eutrophication, aquatic. In D. SIMBERLOFF and M. REJMÁNEK, orgs. Encyclopedia of Biological Invasions. Berkeley: University of California Press, 2011, pp. 209-213.

ESTEVES, F.A. Fundamentos de Limnologia. Rio de Janeiro: Interciência, 2011, 790 p.

ESTEVES, F.A. and CAMARGO, A.F.M. Sobre o papel das macrófitas aquáticas na estocagem e ciclagem de nutrientes. Acta Limnologica Brasiliensia, 1986, 1, 273-298.

FERNANDES, L.F.G., TEIXEIRA, M.C. and THOMAZ, S.M. Diversity and biomass of native macrophytes are negatively related to dominance of an invasive Poaceae in Brazilian sub-tropical streams. Acta Limnologica Brasiliensia, 2013, 25(2), 202-209. http://dx.doi.org/10.1590/S2179975X2013000200011.

GOLTERMAN, H.L., CLYMO, R.S. and OHMSTAD, M.A.M. Methods for physical and chemical analysis of freshwaters. Oxford: Blackwell Scientific Publication, $1978,213 \mathrm{p}$.

HIGUTI, J. Composition, abundance and habitats of benthic chironomid larvae. In S.M. THOMAZ, AA. AGOSTINHO and N.S. HAHN, orgs. The Upper Paraná River and its floodplain: physical aspects, ecology and conservation. Leiden: Backhuys Publishers, 2004, pp. 209-221.

JONES, J.I., COLLINS, A.L., NADEN, P.S. and SEAR, D.A. The relationship between fine sediment and macrophytes in rivers. River Research and Applications, 2011, 28(7), 1006-1018. http://dx.doi.org/10.1002/ rra.1486.

KATAGIRI, K., YABE, K., NAKAMURA, F. and SAKURAI, Y. Factors controlling the distribution of aquatic macrophyte communities with special reference to the rapid expansion of a semi-emergent Phalaris arundinacea L. in Bibi River, Hokkaido, northern Japan. Limnology, 2011, 12(2), 175-185. http://dx.doi.org/10.1007/s10201-010-0335-z.

MICHELAN, T.S., THOMAZ, S.M., CARVALHO, P., BECKER RODRIGUES, R. and JOSÉ SILVEIRA, M. Regeneration and colonization of an invasive macrophyte grass in response to desiccation. Natureza \& Conservação, 2010a, 8(2), 133-139. http://dx.doi. org/10.4322/natcon.00802005.

MICHELAN, T.S., THOMAZ, S.M., CARVALHO, P. and MORMUL, R.P. Effects of an exotic-invasive macrophyte (tropical signalgrass) on native plant community composition, species richness and functional diversity. Freshwater Biology, 2010b, 55(6), 1315-1326. http://dx.doi.org/10.1111/j.13652427.2009.02355.x.

NEWBOLT, C.H., HEPP, GR. and WOOD, C.W. Characteristics of Sediments Associated with
Submersed Plant Communities in the Lower Mobile River Delta, Alabama. Journal of Aquatic Plant Management, 2008, 46, 107-113.

POTT, V.J., POTT, A., LIMA, L.C.P., MOREIRA, S.N. and OLIVEIRA, A.K. Aquatic macrophyte diversity of the Pantanal wetland and upper basin. Brazilian Journal of Biology = Revista Brasileira de Biologia, 2011, 71(1, Suppl 1), 255-263. PMid:21537598.

SANTAMARIA, L. Why are most aquatic plants widely distributed? Dispersal, clonal growth and smallscale heterogeneity in a stressful environment. Acta Oecologica, 2002, 23(3), 137-154. http://dx.doi. org/10.1016/S1146-609X(02)01146-3.

SOUSA, W.T.Z. Hydrilla verticillata (Hydrocharitaceae), a recent invader threatening Brazil's freshwater environments: a review of the extent of the problem. Hydrobiologia, 2011, 669(1), 1-20. http://dx.doi. org/10.1007/s10750-011-0696-2.

TAKEDA, A.M., FUJITA, D.S., KOMATSU, E.H., PAVAN, C.B., OLIVEIRA, D.P., ROSIN, G.C., IBARRA, J.A.A., SILVA, C.P. and ANSELMO, S.F. Influence of Environmental Heterogeneity and Water Level on Distribution of Zoobenthos in the Upper Paraná River Floodplain (Baia and Paraná Rivers). In AGOSTINHO, A.A., RODRIGUES, L., GOMES, L.C., THOMAZ, S.M. and MIRANDA, LE., orgs. Structure and functioning of the Parana River and its floodplain. Maringá: EDUEM, 2004, pp. 91-95.

THIÉBAUT, G. and MARTINEZ, L. An exotic macrophyte bed may facilitate the anchorage of exotic propagules during the first stage of invasion. Hydrobiologia, 2014, 746(1), 183-196. http://dx.doi. org/10.1007/s10750-014-1982-6.

THOMAZ, S.M., CARVALHO, P., MORMUL, R.P., FERREIRA, F.A., SILVEIRA, M.J. and MICHELAN, T.S. Temporal trends and effects of diversity on occurrence of exotic macrophytes in a large reservoir. Acta Oecologica, 2009, 35(5), 614620. http://dx.doi.org/10.1016/j.actao.2009.05.008.

TILMAN, D. The ecological consequences of changes in biodiversity: a search for general principles. Ecology, 1999, 80, 1455-1474.

WU, J., CHENG, S., LIANG, W. and WU, Z. Effects of organic-rich sediment and below-ground sulfide exposure on submerged macrophyte, Hydrilla verticillata. Bulletin of Environmental Contamination and Toxicology, 2009, 83(4), 497-501. http://dx.doi. org/10.1007/s00128-009-9800-y. PMid:19565172

ZAGATTO, E.A.G., JACINTHO, A.O., REIS, B.F., KRUG, F.J., BERGAMIN, H., PESSENDA, L.C., MOR-TATTI, R.J. and GINÉ, M.F. Manual de análises de plantas empregando sistemas de injeção em fluxo. Piracicaba: USP/CENA, 1981, 45 p.

Received: 01 September 2014 Accepted: 03 February 2015 